\title{
Growth, toxin production, active oxygen species and catalase activity of Microcystis aeruginosa (Cyanophyceae) exposed to temperature stress
}

\author{
Leda Giannuzzi a,b, Bernd Krock ${ }^{c}$, Melina Celeste Crettaz Minaglia ${ }^{\text {a,b }}$, Lorena Rosso ${ }^{\mathrm{a}}$, Christian Houghton ${ }^{\mathrm{d}}$, \\ Daniela Sedan ${ }^{\mathrm{a}, \mathrm{b}}$, Gabriela Malanga ${ }^{\mathrm{b}, \mathrm{e}}$, Mariela Espinosa ${ }^{\mathrm{f}}$, Darío Andrinolo ${ }^{\mathrm{a}, \mathrm{b}}$, Marcelo Hernando ${ }^{\mathrm{d}, *}$ \\ a Área de Toxicología, Departamento de Ciencias Biológicas, Facultad de Ciencias Exactas, Universidad Nacional de La Plata, Argentina \\ b CONICET, Buenos Aires, Argentina \\ c Alfred Wegener Institute, Bremerhaven, Germany \\ d Depto. Radiobiología, Comisión Nacional de Energía Atómica, Argentina \\ e IBIMOL-FisicoQuímica, Facultad de Farmacia y Bioquímica, Universidad de Buenos Aires, Argentina \\ ${ }^{\mathrm{f}}$ Gerencia de Química, Comisión Nacional de Energía Atómica, Argentina
}

\section{A R T I C L E I N F O}

\section{Article history:}

Received 29 April 2016

Received in revised form 5 July 2016

Accepted 8 July 2016

Available online 20 July 2016

\section{Keywords:}

Catalase

Chlorophyll

Microcystin variants

ROS

\begin{abstract}
A B S T R A C T
Microcystis are known for their potential ability to synthesize toxins, mainly microcystins (MCs). In order to evaluate the effects of temperature on chlorophyll $a(\mathrm{Chl} a)$, growth, physiological responses and toxin production of a native Microcystis aeruginosa, we exposed the cells to low $\left(23^{\circ} \mathrm{C}\right)$ and high $\left(29^{\circ} \mathrm{C}\right)$ temperature in addition to a $26^{\circ} \mathrm{C}$ control treatment. Exponential growth rate was significantly higher at $29^{\circ} \mathrm{C}$ compared to $23^{\circ} \mathrm{C}$ and control, reaching $0.43,0.32$ and 0.33 day $^{-1}$ respectively. In addition, there was a delay of the start of exponential growth at $23{ }^{\circ} \mathrm{C}$. However, the intracellular concentration of Chl $a$ decreased significantly due to temperature change. A significant increase in intracellular ROS was observed in coincidence with the activation of enzymatic antioxidant catalase (CAT) during the first two days of exposure to $23^{\circ}$ and $29^{\circ} \mathrm{C}$ in comparison to the control experiment, decreasing thereafter to nearly initial values. Five MCs were determined by LC-MS/MS analysis. In the experiments, the highest MC concentration, $205 \mathrm{fg}_{\text {[Leu }}{ }^{1}$ ] MC-LR.cell ${ }^{-1}$ expressed as MC-LR equivalent was measured

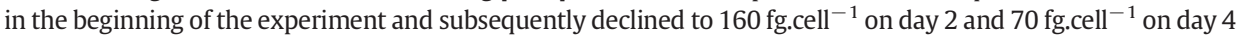
in cells exposed to $29^{\circ} \mathrm{C}$. The same trend was observed for all other MCs except for the least abundant MC-LR which showed a continuous increase during exposure time. Our results suggest a high ability of M. aeruginosa to perceive ROS and to rapidly initiate antioxidant defenses with a differential response on MC production.
\end{abstract}

(C) 2016 Elsevier Inc. All rights reserved.

\section{Introduction}

Due to increase in agricultural and industrial activities, nutrient influx into freshwater ecosystems has increased (Carpenter et al., 1998). Cyanobacteria blooms are associated with eutrophic waters as a consequence of decreased phytoplankton diversity (Oliver and Gand, 2000). Different environmental factors favor the predominance of cyanobacteria, such as high temperatures, irradiance conditions (with optimum values between spring and autumn), ability to fix atmospheric nitrogen, high $\mathrm{pH}$ (6.5 to 8.5), low rate of filtration by zooplankton and the ability to form gas vesicles (Martin, 2000; Paerl and Huisman, 2008). Blooms of toxic cyanobacteria are a global public health and environmental concern. Among cyanotoxins, microcystins (MCs) are considered to be one of the most dangerous groups, which are known to be potent hepatotoxins (Dawson, 1998) and tumor promoters (Zegura et al., 2003). It is believed that MCs are released from cyanobacteria

\footnotetext{
* Corresponding author.

E-mail address: mhernando@cnea.gov.ar (M. Hernando).
}

after cell lysis, whereas only negligible amounts of toxins are apparently released from healthy cells. Over 70 structural analogues of MC have been identified up to date, but only a few occur frequently at high concentrations (Codd et al., 1999; Qi et al., 2015). Minor structural changes may have major effects on uptake, organ distribution and excretion of these toxins (Dietrich and Hoeger, 2005). Recently, Qi et al. (2015) have shown seven new MC variants in the same strain of Microcystis aeruginosa used for the present study, which has been previously reported as a [D-Leu $\left.{ }^{1}\right] M C-L R$ producer (Rosso et al., 2014). MC variants within one cyanobacterial strain may range up to 11 (Krüger et al., 2010). In addition, different temperatures can also be correlated with different MC variants produced (Rapala et al., 1997). Cellular MC production has been indirectly linked to environmental factors influencing cyanobacterial growth rates (Orr and Jones, 1998), which can account for a 3-4 fold variation in total MC concentration (Kurmayer et al., 2002, Kurmayer and Kutzenberger, 2003). In addition, the action mechanisms and the ecophysiological role of toxins remain unclear (Singh et al., 2001; Pflugmacher, 2002; Sedmak and Elersek, 2006; Yoshida et al., 2007). For this reason, the understanding of the 
environmental factors associated with MC production, is necessary to predict toxic events in nature (Hotto et al., 2008).

Increasing fossil fuel emissions and deforestation over the past 250 years have increased atmospheric $\mathrm{CO}_{2}$ concentrations at an unprecedented pace and caused a rise of global average temperatures (Raven et al., 2005). In this century, global temperatures are expected to increase about additional $2-5{ }^{\circ} \mathrm{C}$ (Houghton et al., 2001). Harmful cyanobacteria such as Microcystis have been found to have an optimal temperature for growth and photosynthesis at $25{ }^{\circ} \mathrm{C}$ or above (Reynolds, 2006; Paerl and Huisman, 2008). Furthermore, the cellular toxin content of multiple genera of cyanobacteria increases to a maximum temperature above $30{ }^{\circ} \mathrm{C}$ (Rapala et al., 1997).

Temperature increase stimulates the metabolic rate of the plankton (Zinser et al., 2007). The activation of metabolism implies an increase in oxygen consumption and can lead to an oxidative stress condition in cells. However, the metabolic and physiological responses to increased concentration of reactive oxygen species (ROS) of toxic and non-toxic strains of cyanobacteria to increasing water temperature in has poorly explored. When the production of activated oxygen species is higher compared with the quenching activity of antioxidants, the results will be an oxidative damage (Halliwell, 2006). It has been shown that ROS are responsible for the degradation of $\mathrm{Chl} a$ and the decrease in the activity of photosystem II (PSII) in phytoplankton photosynthetic antenna (Saison et al., 2010). In addition, cause inhibition of cyanobacterial growth (Dziallas and Grossart, 2011). The formation of ROS is prevented by an antioxidant system: low molecular mass antioxidants (ascorbic acid, glutathione, and tocopherols) and ROS-interacting enzymes such as superoxide dismutase (SOD), peroxidases and catalases (CAT) (Lafiti et al. 2009).

Due to the inherent instability and reactivity of most ROS and their very low steady-state levels, their analysis is a much more difficult task than the determination of concentration of antioxidants and the activities of antioxidant enzymes (Jakubowski and Bartosz, 2000).

Therefore, we hypothesized that temperature, like most environmental stresses cited in the literature (e.g., high light, UV-B, drought, salinity, and heavy metals), induced the production of ROS in Microcystis aeruginosa causing oxidative damage and different MC variants production. The purpose of this study was to elucidate the effects of different temperatures on biomass, ROS and MC production as well as enzymatic antioxidant (CAT) activity on Microcystis aeruginosa in culture conditions.

\section{Materials and methods}

\subsection{Experimental set-up}

The experiments were performed with the Microcystis aeruginosa strain CAAT 2005-3, isolated from the drainage canal of the sewage the town of Pila $\left(35^{\circ} 59^{\prime} 49^{\prime \prime} \mathrm{S}-58^{\circ} 08^{\prime} 11^{\prime \prime} \mathrm{W}\right)$, Buenos Aires province, Argentina (Rosso et al., 2014). Two independent set of experiments were conducted and for each treatment temperature in both experiments, all the parameters was evaluated by independent triplicates.

The unialgal cultures were grown in liquid BG-11 (Rippka et al., 1979) at $26{ }^{\circ} \mathrm{C}$, without the addition of such culture medium during the study. For experiments, we used cells from cultures during the exponential growth phase. Three treatments were applied in both experiments: $23{ }^{\circ} \mathrm{C}$ ("low temperature"), $26{ }^{\circ} \mathrm{C}$ ("control") and $29{ }^{\circ} \mathrm{C}$ ("high temperature"). The cells were exposed in a controlled environment growth chamber (Model Standard Infors Multitron) with Shaker equipment $(90 \mathrm{rpm})$ using an independent incubator for each treatment. In order to add cool light photosynthetically active radiance (PAR) a set of 2 fluorescent tubes (Philips TL-DI 8 W/54) were fixed at $20 \mathrm{~cm}$ above each of the triplicate $2 \mathrm{~L}$ Erlenmeyers, with an initial and final (at the end of the experiments) culture medium volume of 1.17 and $1 \mathrm{~L}^{-1}$, respectively. The average irradiance in each incubator was
$30 \mu \mathrm{E} \mathrm{m}^{-2} \mathrm{~s}^{-1}$ (monitored daily with an IL spectroradiometer) under 14:10 h light:dark photocycle.

In order to normalize the values of Chl $a$, cells count, dichlorodihydrofluorescein diacetate (DCF-DA) and CAT from both experiments, each exposure time point was divided by the initial concentrations of the culture used in the corresponding experiment.

\subsection{Sampling procedure for biomass and stress parameters}

Water samples were collected every experimental time at 9:00 AM. Such experimental time was exposure day 0, 1, 2, 3, 4 and 7 days. Culture aliquots for counts were put into $4.5 \mathrm{~mL}$ vials, fixed with acidic Lugol (1\% final concentration) and kept in dark at $10{ }^{\circ} \mathrm{C}$ until analysis. Samples for 2-7- dichlorodihydrofluorescein diacetate (DCF-DA) oxidation rate, for in vivo ROS detection $(30 \mathrm{~mL})$ and CAT $(30 \mathrm{~mL})$ were filtered through a $\mathrm{GF} / \mathrm{F}$ fiber glass filter and measured in vivo those destined to measure ROS (see above) and kept at $-20^{\circ} \mathrm{C}$ until analysis those destined to CAT.

\subsection{Chl a analyses and cell counts}

Pre-filtered samples (GF/F filters) for Chl $a(20 \mathrm{~mL})$ were extracted in $4 \mathrm{~mL}$ acetone $90 \%$ (Jeffrey and Humphrey, 1975). Spectrophotometric readings of the extracts ( $24 \mathrm{~h}$ later) were used for the calculation of $\mathrm{Chl}$ $a$ concentration, after calibration with standard Chl $a$ with a PG spectrophotometer P11.

For the identification and enumeration of cyanobacteria's, cells were analyzed with a phase contrast Olympus inverted microscope according to the procedures described by Villafañe and Reid (1995) using a Sedgwick-Rafter counting chamber.

It was determined the ratio between $\mathrm{Chl} a$ and total cells ( $\mathrm{Chl} \mathrm{a}$ content per cell: quota $\left.\mathrm{Q}_{\mathrm{Chl-a}}\right)$.

\subsection{Growth measurements}

Specific growth rate $\left(\mu\right.$ day $\left.^{-1}\right)$ was calculated separately for each replicate by exponential regression of cell density over time for a defined period of exponential growth (Tillmann et al., 2009).

\subsection{DCFH-DA oxidation rate}

The membrane-permeable non-fluorescent DCFH-DA oxidation has been used for detecting several ROS in biological media (McDowell et al., 2013). Cellular esterases hydrolyze the probe to the nonfluorescent $2^{\prime}, 7^{\prime}$-dichlorodihydrofluorescein $\left(\mathrm{H}_{2} \mathrm{DCF}\right)$. In the presence of ROS and cellular peroxidases, $\mathrm{H}_{2}$ DCF is transformed to the highly fluorescent 2',7'-dichlorofluorescein (DCF) - Cellular accumulation of reactive species was determined by measuring the oxidation of DCFH-DA in vivo. After the filtration of $6 \mathrm{~mL}$ of exposure culture through glass fiber filter, algae cells were incubated in the dark for $30 \mathrm{~min}$ in $2 \mathrm{~mL}$ of $40 \mathrm{mM}$ Tris- $\mathrm{HCl}$ buffer ( $\mathrm{pH} 7.0$ ) in the presence of $5 \mu \mathrm{M}$ DCFH-DA at $27{ }^{\circ} \mathrm{C}$ (Malanga et al., 2001). Fluorescence in the cells suspension was monitored in a microplate reader (Beckman coulter DTX 880, Multimode Detectors) with excitation $\left(\lambda_{\text {ex }}\right)$ at $498 \mathrm{~nm}$ and emission $\left(\lambda_{\mathrm{em}}\right)$ at $525 \mathrm{~nm}$. In all cases parallel blank controls were included.

\subsection{Catalaze activity}

CAT activity was evaluated by the decomposition rate of hydrogen peroxide $\left(\mathrm{H}_{2} \mathrm{O}_{2}\right)$ at $240 \mathrm{~nm}$ at $25^{\circ} \mathrm{C}$ (Beutler, 1982). One unit of CAT was defined as the amount of enzyme catalyzing the elimination of $1 \mathrm{mM} \mathrm{H}_{2} \mathrm{O}_{2}$ per minute.

\subsection{Toxin HPLC/MS analysis}

The first set of experiments (thereafter will be named "analysis 1" where cells were exposed to 23,26 and $29^{\circ} \mathrm{C}$ ) was analyzed by HPLC 
MS. Determining only one principal component of MC toxins which was $\left[\right.$ Leu $\left.^{1}\right]$ MC-LR. The instrument was a single quadrupole system (Shimadzu LCMS-2020).

In order to amplify the $\mathrm{MC}$ information and evaluate differences in the toxin profiles between control and $29^{\circ} \mathrm{C}$, the second set of experiments (thereafter will be named "analysis 2 ") was performed. In this experiment, we conducted a more specific study thorough determination of MC variants by LC-MS/MS (4000 Q Trap, AB-SCIEX, Darmstadt, Germany).

The LC equipment included a solvent reservoir, in-line degasser (G1379A), binary pump (G1311A), refrigerated autosampler (G1329A/ G1330B), and temperature-controlled column oven (G1316A).

For both analyses, cell pellets from $5 \mathrm{~mL}$ filtration cultures were extracted with $500 \mu \mathrm{L}$ methanol by ultrasonication (Sonoplus HD 2070, Bandelin, Berlin, Germany; 70sek/70 cycles/10\%power). Extracts were then centrifuged (Eppendorf 5415 R, Hamburg, Germany) at $16,100 \times g$ at $4{ }^{\circ} \mathrm{C}$ for $10 \mathrm{~min}$. Each supernatant was transferred to a $0.45-\mu \mathrm{m}$ pore-size spin-filter (Millipore Ultrafree, Eschborn, Germany) and centrifuged for $30 \mathrm{~s}$ at $800 \times \mathrm{g}$. For LC-MS/MS analysis the resulting filtrate being transferred into an LC autosampler vial.

\subsubsection{Single ion monitoring (SIM) measurements (analysis 1)}

Milli-Q grade water, formic acid (96\%, HPLC quality, Tedia, USA) and acetonitrile (LC-MS grade, Tedia, USA) were used.

Separation of MCs ( $50 \mu \mathrm{L}$ sample injection volume) was performed by reverse-phase chromatography on a C18 phase. The analytical column $(150 \times 4.6 \mathrm{~mm})$ was packed with $5 \mu \mathrm{m}$ (Thermo) and maintained

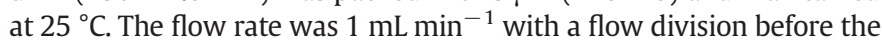
entrance to the ESI $\left(0.2 \mathrm{~mL} \mathrm{~min}^{-1}\right.$.to the ESI-MS). The gradient elution was performed with two eluents, where eluent A was water and B was acetonitrile, both containing $12.7 \mathrm{mM}$ formic acid. Initial conditions were $30 \% \mathrm{~B}$, followed by a linear gradient to $70 \% \mathrm{~B}$ in $12 \mathrm{~min}, 3 \mathrm{~min}$ isocratic elution with $70 \% \mathrm{~B}$, then a linear gradient to $30 \%$ B in 5 min (total run time: $20 \mathrm{~min}$ ).

\subsubsection{Single reaction monitoring (SRM) measurements (analysis 2)}

Water was deionized and purified (Milli-Q, Millipore, Eschborn, Germany) to $18 \mathrm{M} \Omega \mathrm{cm}^{-1}$ or better quality. Formic acid (90\%, p.a.), acetic acid (p.a.) and ammonium format (p.a.) were purchased from Merck (Darmstadt, Germany). The solvents, methanol and acetonitrile, were high performance liquid chromatography (HPLC) grade (Merck, Darmstadt, Germany).

Separation of MCs ( $5 \mu \mathrm{L}$ sample injection volume) was performed by reverse-phase chromatography on a C18 phase. The analytical column $(150 \times 3 \mathrm{~mm})$ was packed with $3 \mu \mathrm{m}$ Luna $100 \AA$ (Phenomenex, Aschaffenburg, Germany) and maintained at $20{ }^{\circ} \mathrm{C}$. The flow rate was $0.2 \mathrm{~mL} \mathrm{~min}^{-1}$ and gradient elution was performed with two eluents, where eluent A was water and B was methanol/water (95:5 v/v), both containing $2.0 \mathrm{mM}$ ammonium format and $50 \mathrm{mM}$ formic acid. Initial conditions were $100 \% \mathrm{~B}$, followed by a linear gradient to $50 \% \mathrm{~B}$ in 1 min, isocratic elution min with $50 \%$ B until 5 then a linear gradient to $90 \%$ B until 15 min followed by isocratic elution with $90 \%$ B until $20 \mathrm{~min}$ and returning to initial conditions until $21 \mathrm{~min}$ followed by 9 min column equilibration with $0 \%$ B (total run time: $30 \mathrm{~min}$ ).

For the samples evaluated with quadrupole equipment MC profiles were determined in one period min with curtain gas: 15 psi, CAD: medium, ion spray voltage: $5500 \mathrm{~V}$, temperature: $550{ }^{\circ} \mathrm{C}$, nebulizer gas: 50 psi, auxiliary gas: 60 psi, interface heater: off, declustering potential: $45 \mathrm{~V}$, entrance potential: $10 \mathrm{~V}$, exit potential: $12 \mathrm{~V}$, collision energy: $50 \mathrm{~V}$. SRM experiments were carried out in positive ion mode by selecting the transitions $m / z 498>135$ (MC-LR), $512>135$ ([ Leu $^{1}$, Asp $\left.^{3}\right]$ MC-LR), $519>135$ ([Leu $\left.\left.{ }^{1}\right] \mathrm{MC}-\mathrm{LR}\right), 526>135\left(\left[\mathrm{Leu}^{1}\right.\right.$, Glu $\left.\left(\mathrm{OCH}_{3}\right)^{6}\right] \mathrm{MC}-$ LR) and $536>135\left(\left[\mathrm{M}(\mathrm{O})^{1}\right] \mathrm{MC}-\mathrm{LR}\right)$. Samples were measured against an external standard solution of MC-LR (certified reference material (CRM) programme of the IMB-NRC, Halifax, Canada) and expressed as MC-LR equivalents.

\subsection{Statistical analyses}

Repeated measurements ANOVA (RMANOVA) were performed (Statistica, version 9) to determine the significance of the differences observed in Chl $a$, cells biomass, $Q_{\text {Chl-a }}$, DCF-DA and CAT values during experiment at different temperatures. Normality was verified using a one-sample Kolmogorov-Smirnov test, whereas the sphericity assumption that concerns variance homogeneity was checked using Mauchley's test. The main factors considered in the analysis were the number of days of exposure and the type of treatment. Tukey test was additionally performed to determine the differences between treatments. When interaction was significant or the assumptions of sphericity were not satisfied, a one factor ANOVA was performed evaluating the effect of treatment at different days of exposure (Scheiner, 2001). To analyze the significance of the differences observed between Chl $a$ and Cells biomass as a function of exposure time for the three treatments, a Pearson correlation coefficient analysis was applied.

\section{Results}

\subsection{M. aeruginosa biomass and abundance}

The initial average concentration of Chl $a$ was 1950 and $900 \mu \mathrm{g}$ Chl $a$ $\mathrm{L}^{-1}$ for experiment 1 and 2 respectively. Chl $a$ concentrations increased during the first 2 days in all temperature treatments, being significantly higher at $29^{\circ} \mathrm{C}$ compared to $23^{\circ} \mathrm{C}$ and control during day 1 of the experiment $(P<0.01$; Fig. 1$)$. Subsequently, the Chl $a$ values gradually declined until the end of the experiment, being significantly higher at $29{ }^{\circ} \mathrm{C}$ during day 4 in comparison to control and $23{ }^{\circ} \mathrm{C}$ treatment. At $23^{\circ} \mathrm{C}$ Chl $a$ values were lowest during day 3 and 4 , being significantly lower compared to control treatment during day $4(P<0.05)$. All Chl $a$ concentrations reached lowest average values on day 7 , the lowest in the $29^{\circ} \mathrm{C}$ treatment $(P>0.05$, Fig. 1$)$.

The initial average concentration of cells was 1100 and $880 \times$ $10^{3}$ cells $\mathrm{mL}^{-1}$ for experiment 1 and 2 respectively. Total cyanobacterial cell numbers started to increase from day 1 of exposure. At such time, the biomass was significantly higher in $29^{\circ} \mathrm{C}(P<0.01)$ compared to $23{ }^{\circ} \mathrm{C}$ and control, which did not show significant differences between them ( $P>0.05$; Fig. 2 ). Maximum cell numbers were reached on day 3 in control and $29^{\circ} \mathrm{C}$ treatment, being significantly higher at $29^{\circ} \mathrm{C}$ compared to $23^{\circ} \mathrm{C}$ and control $(P<0.01)$. In addition at day 4 the cell number of cultures exposed to $23{ }^{\circ} \mathrm{C}$, were significantly higher

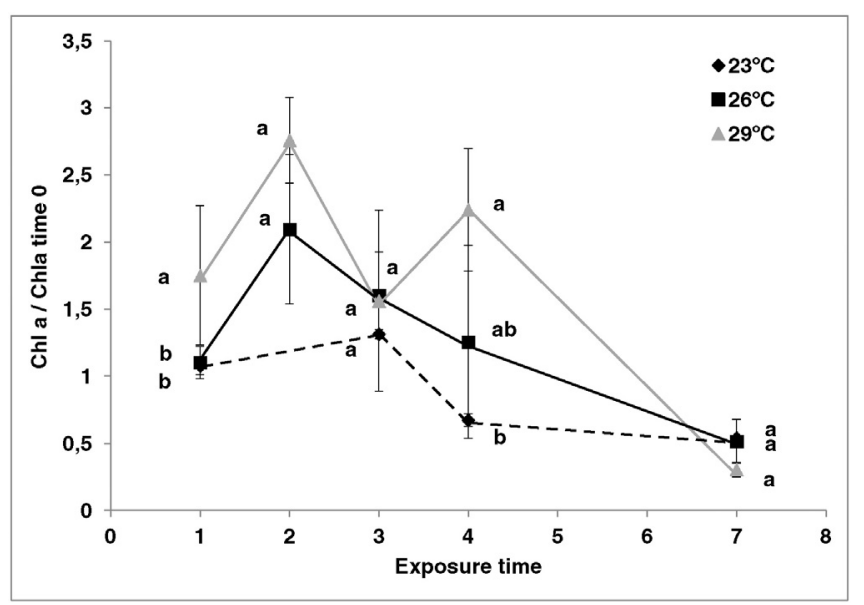

Fig. 1. Time course of $\mathrm{Chl} a$ (normalized to initial values) during temperature exposure. Each point represents the mean \pm standard deviation of the mean $(\mathrm{N}=36$ and 24 independent replicates for total experiment 1 and 2 respectively) Different letters correspond to significant differences between treatments for the same day. Treatments with the same letter are not significantly different from each other values $(P>0.05)$ (Tukey Test). 


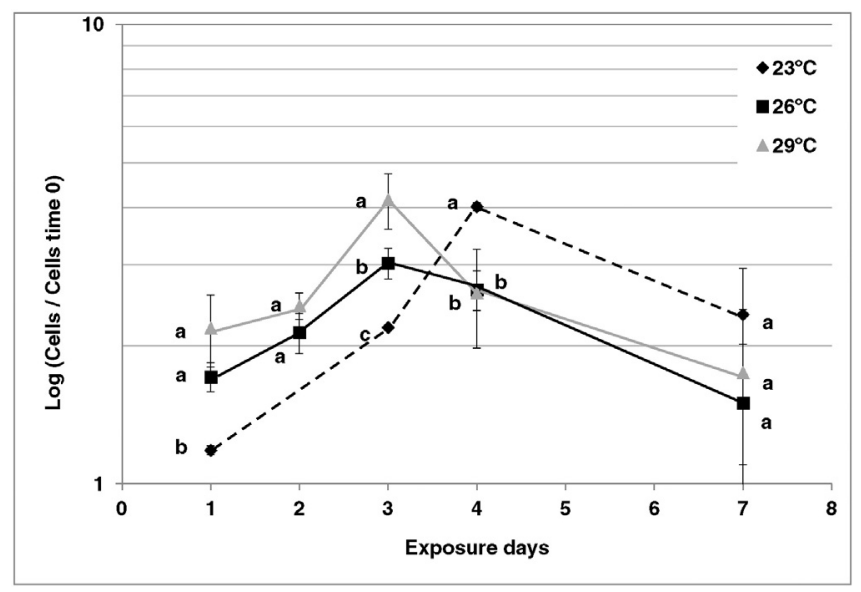

Fig. 2. Time course of cell biomass (normalized to initial values) during temperature exposure. Each point represents the mean \pm standard deviation of the mean $(\mathrm{N}=36$ and 24 independent replicates for total experiment 1 and 2 respectively). Different letters correspond to significant differences between treatments for the same day. Treatments with the same letter are not significant different from each other values $(P>0.05)$ (Tukey Test).

compared with those exposed to $26{ }^{\circ} \mathrm{C}$ and $29{ }^{\circ} \mathrm{C}(P<0.01)$. Therefore, cyanobacteria exposed to $23^{\circ} \mathrm{C}$ continued growing until day 4 reaching the maximum biomass values observed from cultures exposed to $29^{\circ} \mathrm{C}$ at the end of the exponential growth phase (day 3, Fig. 2). For days 4 and 7, the cyanobacterial biomass at $23{ }^{\circ} \mathrm{C}$ and in control decreased without any significant differences between them $(P>0.05)$ but being significantly lower compared to cells exposed to $29{ }^{\circ} \mathrm{C}$ on day 4 $(P<0.01)$. For the last exposure day the cell numbers did not show any significant differences between temperatures $(P>0.05$, Fig. 2$)$. The onset of exponential growth started during the first experimental day and did not show differences between treatments. RMANOVA analyses for total cell abundance showed a significant statistical interaction between treatments and exposure time $(P<0.05)$. Despite the fact that there were no significant differences between the specific growth rates of cells exposed to $23^{\circ} \mathrm{C}$ and in control $\left(0.31\right.$ and 0.33 day $^{-1}$, respectively, $P>0.05)$, the specific growth rates were significantly higher in cells exposed to $29{ }^{\circ} \mathrm{C}\left(0.43\right.$ day $\left.^{-1}\right)$ compared to $23{ }^{\circ} \mathrm{C}$ and control $(P<0.01)$. Chl $a$ and cell density did not show statistically significant linear relationship between the three treatments $(r=0.55 ; 0.35$ and 0.56 $p>0.05$ for 23,26 and $29{ }^{\circ} \mathrm{C}$ respectively). The quota $Q_{\text {Chl-a }}$ increased during the first 2 days in all treatments. It was significantly lower for the first day in the control compared to $23{ }^{\circ} \mathrm{C}$ and $29{ }^{\circ} \mathrm{C}(P<0.01)$, which did not show any significant differences between them $(P>0.05$, Fig. 3$)$. At 2 days there were no significant differences of $\mathrm{Q}_{\text {chl-a }}$ between temperatures treatments $(P>0.05)$. During the following days, $Q_{\text {Chl-a }}$ decreased until the end of the experiment, being higher in control than in the temperature treatments $(P<0.05$ for days 3 and 7 and $P<0.01$ for day 4$)$. For days 4 and 7 the $\mathrm{Q}_{\mathrm{Chl}-\mathrm{a}}$ in the $23^{\circ} \mathrm{C}$ treatment did not show significant differences to those from $29{ }^{\circ} \mathrm{C}$ treatment $(P>0.05$, Fig. 3).

\section{2. $R O S$ and catalase}

The DCF-DA oxidation rate (initial average values $0.25 \mathrm{UA} \mathrm{h}^{-1}$ cells $^{-1}$ ) showed similar values throughout the experiment when cyanobacteria were exposed to control temperature $\left(26^{\circ} \mathrm{C}\right)$, being slightly higher during the first exposure day $(P>0.05)$ (Fig. 4). However, cells in the high temperature $\left(29^{\circ} \mathrm{C}\right)$ treatment showed a significant increase of ROS $(P<0.01$, Fig. 4$)$ compared to control in low temperature conditions. In contrast, after 2 days DCF-DA values were significantly higher in control than at $29^{\circ} \mathrm{C}(P<0.01$, Fig. 4$)$. During the 4th exposure day, DCF-DA in cells exposed to $29^{\circ} \mathrm{C}$ showed a new significant decrease $(P<0.01)$ compared with control and $23^{\circ} \mathrm{C}(P>0.05$, Fig. 4).

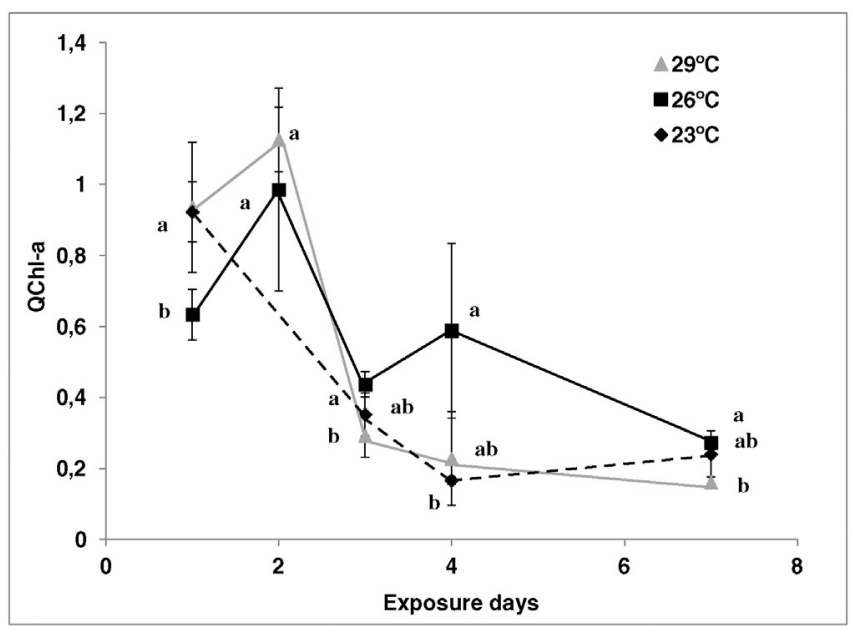

Fig. 3. Temporal evolution of $\mathrm{Chl}$ a/cells ratio during temperature exposure. Each point represents the mean \pm standard deviation of the mean $(\mathrm{N}=36$ and 24 independent replicates for total experiment 1 and 2 respectively). Different letters correspond to significant differences between treatments for the same day. Treatments with the same letter are not significantly different from each other values $(P>0.05)$ (Tukey Test).

Regarding to catalase activity (initial average values $5 \times$ $10^{-16}$ pmol cells $^{-1}$ ), it was not observed any significant difference in cells exposed to control temperature during all the experiment $(P>0.05$, Fig. 5). However, it was observed a slight increase in cells after 2 days of exposure in coincidence with the decrease in ROS at such time (Fig. 4). The maximum activity values were reached after 1 day exposure in cells exposed to $29^{\circ} \mathrm{C}$, being higher compared to the exposure to $23^{\circ} \mathrm{C}$ and control $(P<0.01)$. During day 1 , catalase activity was higher in $23^{\circ} \mathrm{C}$ than in control $(P<0.01)$. After 2 days, catalase activity at $29{ }^{\circ} \mathrm{C}$ remained with a tendency to stay high compared to cells exposed to control temperature $(P>0.05$, Fig. 5$)$, in coincidence with the decline of ROS at $29^{\circ} \mathrm{C}$ (Fig. 4). On the 3rd day, the catalase activity was higher at $23^{\circ} \mathrm{C}$ compared to control and $29^{\circ} \mathrm{C}(P<0.05)$. On day 4 a further increase was observed in the catalase activity from cells exposed to $29{ }^{\circ} \mathrm{C}(P<0.01)$ compared to $23{ }^{\circ} \mathrm{C}$ and control $(P>0.05$, Fig. 5) in coincidence with the decrease of ROS at high temperature

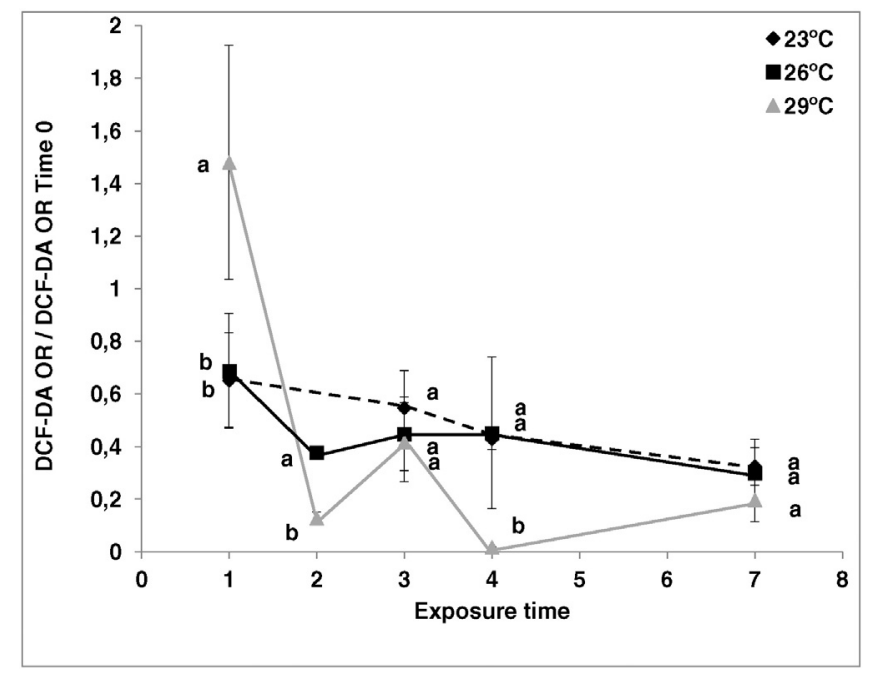

Fig. 4. Effect of temperature on oxidative stress parameters in $M$. aeruginosa as a function of exposure time. DCFH-DA oxidation rate (expressed as arbitrary units in $1 \mathrm{~h}$ exposure) relative to T0 values. Each point represents the mean \pm standard deviation of the mean ( $\mathrm{N}=36$ and 24 independent replicates for total experiment 1 and 2 respectively). Different letters correspond to significant differences between treatments for the same day. Treatments with the same letter are not significantly different from each other values $(P>0.05)$ (Tukey Test). 


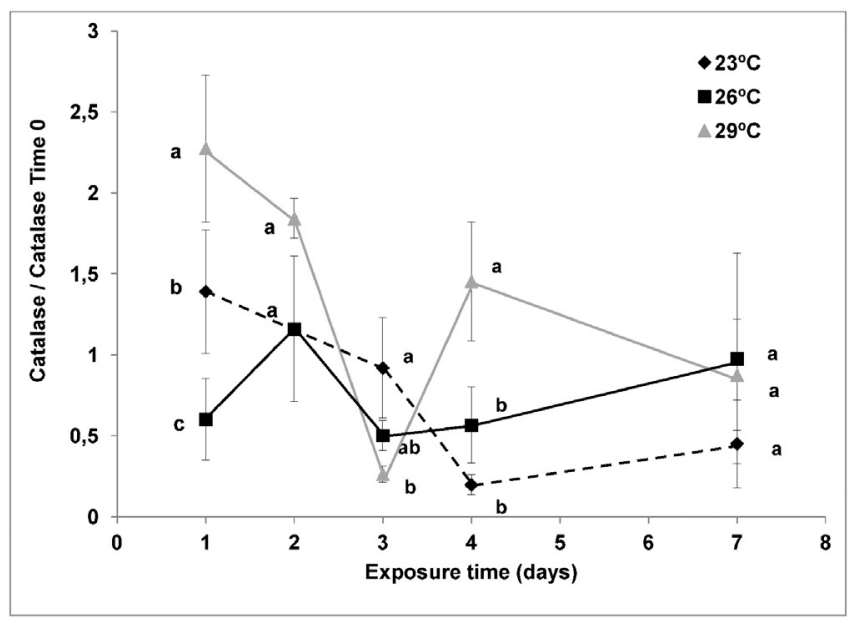

Fig. 5. Enzymatic catalase antioxidants activity normalized to T0 values. Each point represents the mean \pm standard deviation of the mean $(\mathrm{N}=36$ and 24 independent replicates for total experiment 1 and 2 respectively). Different letters correspond to significant differences between treatments for the same day. Treatments with the same letter are not significantly different from each other values $(P>0.05)$ (Tukey Test).

(Fig. 4). Towards the end of the experiment there were no differences between treatments $(P>0.05$, Fig. 5$)$.

\subsection{Toxins}

\subsubsection{MC toxin profile characterization}

The samples evaluated in positive ion mode with a triple quadrupole tandem mass spectrometer showed five of the ten MCs which had previously been observed by Qi et al. (2015) using a more sensitive ion cyclotron resonance (ICR) mass spectrometer. These five MCs were: MC-LR, $\left[\mathrm{Leu}^{1}\right] \mathrm{MC}-\mathrm{LR},\left[\mathrm{Leu}^{1}, \mathrm{Asp}^{3}\right] \mathrm{MC}$-LR, $\left[\mathrm{Leu}^{1}, \mathrm{Glu}\left(\mathrm{OCH}_{3}\right)^{6}\right] \mathrm{MC}-\mathrm{LR}$ and $\left[\mathrm{M}(\mathrm{O})^{1}\right] \mathrm{MC}-\mathrm{LR}$ (Fig. 6).

\subsubsection{Intracellular MC concentration}

The most abundant MC was [Leu ${ }^{1}$ ] MC-LR. It was expressed as toxin per cell (quota $\mathrm{Q}_{[\text {Leu }}{ }^{1}{ }_{1}$ MC-LR $)$ with levels of 380 and $202 \mathrm{fg} \mathrm{cell}^{-1}$ (expressed as MC-LR equivalent) in the beginning of the analysis 1 and 2, respectively. In the subsequent days, the $\mathrm{Q}_{[\text {Leu }] \text { MC-LR }}$ decreased significantly in both experiments. During the second set of experiments the $\mathrm{MC}$ variation at $23{ }^{\circ} \mathrm{C}$ was not evaluated considering that the

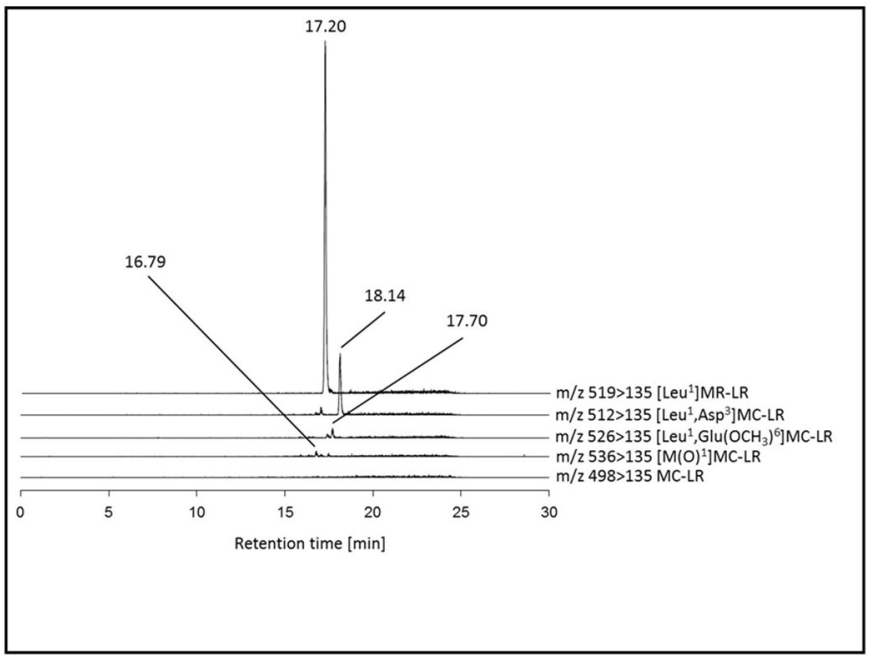

Fig. 6. Five Selected Reaction Monitoring (SRM) ion traces of Microcystis strain CAAT 2005-3: $m / z$ 498/135 (MC-LR); $m / z$ 512/135 ([Leu ${ }^{1}$, Asp $\left.^{3}\right]$ MC-LR); $m / z$ 519/135 ([Leu $\left.\left.{ }^{1}\right] \mathrm{MC}-\mathrm{LR}\right) ; m / z$ 526/135 ([Leu ${ }^{1}$, Glu(OCH $\left.\left.\left.{ }_{3}\right)^{6}\right] \mathrm{MC}-\mathrm{LR}\right) ; m / z$ 536/135 ([M(O) $\left.\left.{ }^{1}\right] \mathrm{MC}-\mathrm{LR}\right)$.

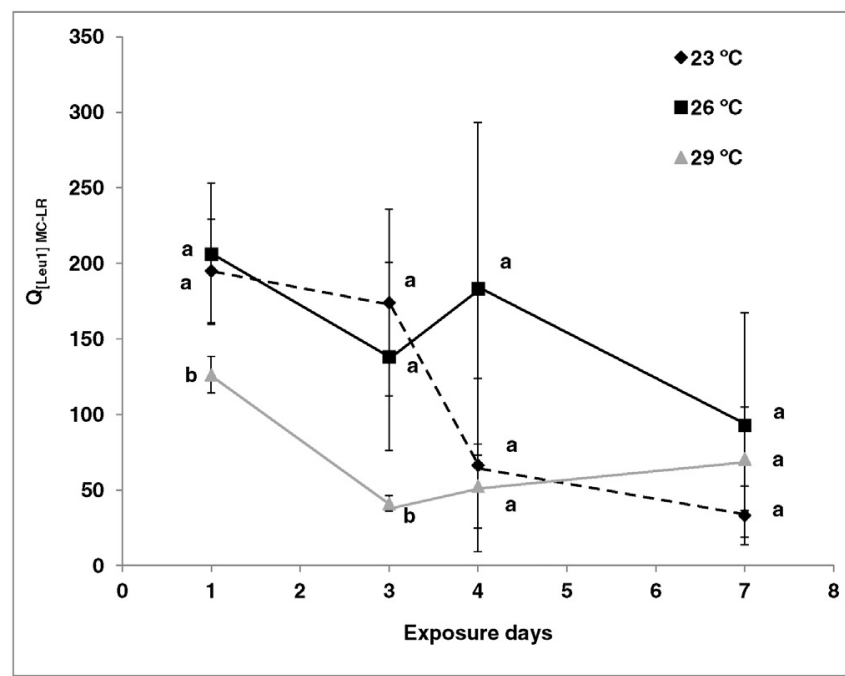

Fig. 7. Effect of temperature on $\mathrm{Q}_{[\text {Leu1] }} \mathrm{MC}$-LR. Each point represents the mean \pm standard deviation of the mean ( $\mathrm{N}=24$ independent replicates for all the experiment). Different letters correspond to significant differences between treatments for the same day. Treatments with the same letter are not significantly different from each other values $(P>0.05)$ (Tukey Test).

principal temperature impacts on biomass, ROS and CAT activity was observed at $29^{\circ} \mathrm{C}$. For the analysis 1 , the $\mathrm{Q}_{[\text {Leu }] \text { MC-LR }}{ }^{1}$ for cells exposed to $29^{\circ} \mathrm{C}$ were significantly lower $(P<0.01)$ compared to those observed at $23^{\circ} \mathrm{C}$ and control during exposure days 1 and 3, which didn't show significant differences between them $(P>0.05)$. During days 4 and 7 there was no significant differences between treatments, despite the fact that the toxin cell content at 23 and $29^{\circ} \mathrm{C}$ were of low concentration compared with control (Fig. 7). For analysis 2, there was no significant

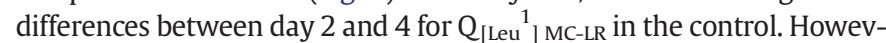
er, at $29^{\circ} \mathrm{C}$ the $\mathrm{Q}_{\text {[Leu1] MC-LR }}$ on day 4 was significantly lower $(P<0.01)$ compared to the previous days (Table 1 ). The same trend was observed for the other MCs. For $\mathrm{Q}_{[\mathrm{Leu}}{ }_{\text {, Glu (OCH3)6] MC-LR }}$ and $\mathrm{Q}_{[\mathrm{M}(\mathrm{O}) 1 \mathrm{MC}-\mathrm{LR}] \text {, }}$ at $29^{\circ} \mathrm{C}$ on day 4 , a significant decrease was observed, despite an increase of both toxins at $29{ }^{\circ} \mathrm{C}$ compared to control on day 2. $\mathrm{Q}_{[\text {Leu }}{ }^{1}$,Asp $\left.{ }^{3}\right]$ MC-LR

Table 1

Results of parametric analysis of variance repeated measures showing the significance of increased temperature on individual MC quotas in fg cell $^{-1}$ of analysis 2 for 26 and 29 ${ }^{\circ} \mathrm{C}$. Each point represents the mean $\pm \mathrm{SD}$. Significant (Tukey Test) differences between treatments at the same day are shown with the corresponding $P$ values.

\begin{tabular}{|c|c|c|c|}
\hline & $26^{\circ} \mathrm{C}$ & $29^{\circ} \mathrm{C}$ & $\begin{array}{l}\text { Significance } \\
\text { level }(P)\end{array}$ \\
\hline \multicolumn{4}{|l|}{$M C-L R$} \\
\hline Day 0 & $25,6 \pm 5$ & $0,3 \pm 0,04$ & $<0,01$ \\
\hline Day 2 & $10,5 \pm 4,6$ & $4,3 \pm 3,5$ & 0,15 \\
\hline Day 4 & $7,78 \pm 6$ & $12,9 \pm 2,9$ & 0,46 \\
\hline \multicolumn{4}{|c|}{ 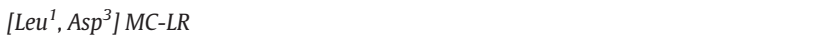 } \\
\hline Day 0 & $17,2 \pm 2,1$ & $14,6 \pm 2,6$ & 0,06 \\
\hline Day 2 & $10,4 \pm 1,6$ & $10,7 \pm 0,4$ & 0,63 \\
\hline Day 4 & $8,7 \pm 0,3$ & $5,4 \pm 0,4$ & $<0,05$ \\
\hline \multicolumn{4}{|c|}{$\left[\operatorname{Leu}^{1}\right] M C-L R$} \\
\hline Day 0 & $202 \pm 9,6$ & $207 \pm 31$ & 0,08 \\
\hline Day 2 & $143 \pm 7$ & $162 \pm 19$ & 0,29 \\
\hline Day 4 & $163 \pm 10$ & $75 \pm 12$ & $<0,01$ \\
\hline \multicolumn{4}{|c|}{$\left[\mathrm{Leu}^{1}, \mathrm{Glu}\left(\mathrm{OCH}_{3}\right)^{6}\right] M C-L R$} \\
\hline Day 0 & $7,2 \pm 0,2$ & $8,3 \pm 0,8$ & 0,06 \\
\hline Day 2 & $4,4 \pm 0,5$ & $6,9 \pm 0,7$ & $<0,01$ \\
\hline Day 4 & $4,69 \pm 0,2$ & $3,5 \pm 0,7$ & 0,05 \\
\hline \multicolumn{4}{|c|}{$\left[M(0)^{1}\right] M C-L R$} \\
\hline Day 0 & $4,1 \pm 0,7$ & $3,5 \pm 0,7$ & 0,06 \\
\hline Day 2 & $1,9 \pm 0,4$ & $3,2 \pm 0,5$ & $<0,05$ \\
\hline Day 4 & $2,1 \pm 0,2$ & $1,4 \pm 0,4$ & $<0,05$ \\
\hline
\end{tabular}




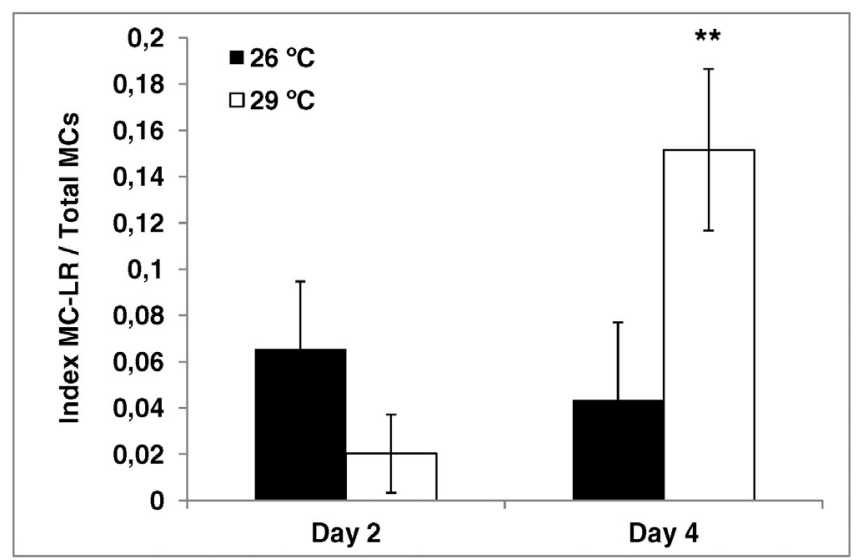

Fig. 8. Index MC-LR quota relative to total MCs quota as a function of exposure days. Each point represents the mean \pm SD. Significant differences between treatments on the same day are denoted with a ${ }^{* *}$ for $P<0.01$ (Tukey Test).

exposed to $29^{\circ} \mathrm{C}$, was only significantly lower than control on day 4 (Table 1). In contrast, $Q_{M C-L R}$ showed the opposite trend, namely a significant increase from an initial value of 0.3 fg.cell $^{-1}$ at day 0 to 12.9 fg.cell ${ }^{-1}$ at day 4 at $29^{\circ} \mathrm{C}$ (Table 1 ). The $\mathrm{Q}_{\text {MC-LR }}$ relative to total MC index was significantly higher at day $4(P<0.01)$ when cells were exposed to $29^{\circ} \mathrm{C}$ (Fig. 8).

\section{Discussion}

The growth of cells, in all treatments of our experiment, was a typical example of batch culture growth. However, the rapid decline of cells could be due to the high initial cells inoculums (average initial concentration $9 \times 10^{5}$ cells $\mathrm{mL}^{-1}$ ) and the consequent rapid nutrient consumption. High cell densities were necessary in order to overcome the detection limit of oxidative stress analysis with a daily minimum sampling avoiding the experimental edge effect. Thus only $10 \%$ of the experimental culture volume was used during the overall experiment. Cyanobacterial blooms have increased in frequency in last decades. Warmer temperatures and eutrophication are often proposed as principal factors which promote these events (Chorus and Bartram, 1999; Paerl and Huisman, 2008). In the current century, global temperatures are expected to increase an additional $2-5^{\circ} \mathrm{C}$ (Houghton et al., 2001). In this study, the relative change of biomass (both in terms of Chl a. $\mathrm{mL}^{-1}$ and cells. $\mathrm{mL}^{-1}$ ) and the change in $\mathrm{Q}_{\mathrm{chl} \text {-a }}$ were affected by changes of temperature in M. aeruginosa. It was evident from our data that during the initial days of exposure the cyanobacteria were adjusting to new conditions of low temperature $\left(23{ }^{\circ} \mathrm{C}\right)$. Li et al. (2014) reported a significant decrease in specific growth rate of M. aeruginosa when was incubated at $20^{\circ} \mathrm{C}$ in comparison with the incubation at $25^{\circ} \mathrm{C}$. This probably means that cells have to invest a significant amount of energy in the synthesis of antioxidant enzymes (will be discussed later) and repair mechanisms at the expenses of biosynthesis of organic compounds. Despite these results, we found no significant differences in the specific growth rate comparing low and control temperature. This suggested that cells were able to grow at $23^{\circ} \mathrm{C}$, and that the only significant effect was the delay in the onset of the exponential growth phase. Similar acclimation to low temperature was reported by Imai et al. (2009) comparing the effect of temperature on the growth rates of $M$. aeruginosa and $M$. wesenbergii. In the same study $M$. aeruginosa has a significant higher growth rate when was incubated at $30{ }^{\circ} \mathrm{C}\left(0,5 \mathrm{day}^{-1}\right)$ compared with those incubated at $25{ }^{\circ} \mathrm{C}$ $\left(0.3\right.$ day $\left.^{-1}\right)$ and $20{ }^{\circ} \mathrm{C}\left(0.18\right.$ day $\left.^{-1}\right)$. We observed a similar response in our experiment considering that the exponential growth rate of cells exposed to $29^{\circ} \mathrm{C}$ was significantly higher compared to those observed at $23{ }^{\circ} \mathrm{C}$ and control $\left(0.43,0.32\right.$ and 0.33 day $^{-1}$ respectively). However, Mowe et al. (2015) didn't show any significant differences after expose to M. aeruginosa to increased temperature (from $28{ }^{\circ} \mathrm{C}$ to $33{ }^{\circ} \mathrm{C}$ with a growth rate of 0.6 and 0.7 day $^{-1}$ respectively, $P>0.05$ ). Probably the differences in growth responses (Japan/Argentina $v s$ Singapore) could be attributed to different experimental conditions and/or possible differences in specific adaptation mechanisms since the strain exposed by Mowe et al. (2015), was isolated from tropical area where they grow at $30{ }^{\circ} \mathrm{C}$ with a minimum thermal amplitude. The strains from Japan (Imai et al., 2009) and ourselves were isolated from temperate area where they grow at $25^{\circ} \mathrm{C}$ with a high annual thermal amplitude. In addition, an increased growth rate of $M$. aeruginosa when was incubated at $29^{\circ} \mathrm{C}$ in comparison with control, was reported by Reynolds (2006). Generally, in temperate region, water temperature increases from spring to early summer and decreases from midsummer to autumn. Thus, in the natural environment, $M$. aeruginosa may dominate early in the year because it responds to a seasonal rise in water temperature. Ohkubo et al. (1993) have reported that the cell density of $M$. aeruginosa was highly correlated with water temperature in Lake Kasumigaura.

The reduction in chlorophyll content due to different stresses may be the result of inhibition of chlorophyll biosynthesis by inhibition of $\alpha$-aminolevulinic acid dehydrogenase and protochlorophyllide reduc-

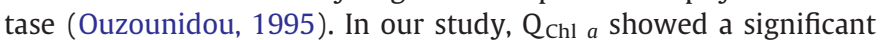
decrease over exposure time after 2 days in all treatments. It was observed a significant decrease of $\mathrm{Q}_{\mathrm{Chl}}$ a for cells exposed to $29^{\circ} \mathrm{C}$ on days 3,4 and 7 and for those exposed to $23^{\circ} \mathrm{C}$ on day 4 . The same tendency was observed in field samples from Furuike Pond (Japan) (Imai et al., 2009). In our experiments, the decrease of $Q_{\mathrm{Chl}}$ starting at day 3 could be produced by an increased ROS concentration on day 3 and 7 with respect to the previous days. Similar results were presented by (He et al. (2002)), who reported that ROS formation in Anabaena sp. resulted in Chl $a$ bleaching and damage of the photosynthetic apparatus.

Photosynthetic organisms may be exposed to ROS because they have photochromic pigments and as consequence they simultaneously produce and consume oxygen during exposure to light. The photosynthetic electron transport system is the major source of active oxygen species during photosynthetic light reactions (Asada, 1999). In particular for cyanobacteria, proteins bearing colored prosthetic groups, such as phycobiliproteins, can be both the source and target of singlet oxygen $\left({ }^{1} \mathrm{O}_{2}\right)$ with consequent loss of the macromolecular biological functions (Michaeli and Feitelson, 1995).

The chemistry of oxygen species had been largely studied (Imlay, 2003). DCFH-DA was initially thought to be useful as a specific indicator for hydrogen peroxide. However, it was already demonstrated that $\mathrm{H}_{2}$ DCF is oxidized by other ROS, including superoxide anion radical, hydroxyl radical, peroxyl, alkoxyl, hydroperoxyl and peroxynitrite which are products of normal metabolism (Halliwell and Gutteridge, 2007). Intracellular production of ROS does not necessarily imply cellular toxicity, but oxidative stress will occur when ROS formation exceeds antioxidant defense capability or disrupts redox signaling, affecting cell functionality (Häubner et al., 2014). DCF can be oxidized by various ROS including $\mathrm{H}_{2} \mathrm{O}_{2}$, organic hydroperoxides, nitric oxide and peroxynitrite (Gomes et al., 2005). In our experiment, an increase of DCFH-DA oxidation was only evident for the first day in the $29{ }^{\circ} \mathrm{C}$ treatment. ROS in high concentrations can be extremely harmful to cell constituents (Valavanidis et al., 2006). Oxidative stress has been linked to a number of cellular toxic processes, including damages to proteins, membrane lipid peroxidation, enzyme inactivation and DNA breakage (Halliwell and Gutteridge, 2007). The fact that the cellular ROS concentrations decreased significantly during the subsequent days in relation to control, could be related to consumption of antioxidants (Mittler, 2002). $\mathrm{H}_{2} \mathrm{O}_{2}$ is the most stable ROS and to avoid damage by $\mathrm{H}_{2} \mathrm{O}_{2}$ in cyanobacteria, they have evolved various enzymes that are able to detoxify this compound. Two of these are catalase (CAT) and glutathione peroxidase $(\mathrm{GP})$. Catalases are one of the most-studied enzymes that exclusively dismutate $\mathrm{H}_{2} \mathrm{O}_{2}$ (Chelikani et al., 2004). In our experiment CAT activity increased for cells exposed to $29^{\circ} \mathrm{C}$ until day 4 , except for 
the 3rd day in which no differences were found in comparison to control. This observation could explain the significant decrease in ROS and avoiding DNA damage and consequent increased growth rate, observed at $29^{\circ} \mathrm{C}$. The same trend was observed at $23^{\circ} \mathrm{C}$ where CAT activity increased on days 1 and 3 . Such results could explain the decreased ROS concentration to values that were not significantly different to the control treatment. However, a lower activity of CAT compared to cells exposed to $29{ }^{\circ} \mathrm{C}$ could have negative effects on DNA integrity which could be traduced in an increased lag period for the first exposure days. Oxidative damage to DNA by ROS is involved in the decrease of growth and survival (Jordan 1996; Franklin et al. 1997). Bifidobacteria are sensitive to oxidative stress and prevent the damage to DNA by CAT (Zuo et al., 2014). Even though DNA is not the direct target of $\mathrm{H}_{2} \mathrm{O}_{2}$ and $\mathrm{O}_{2}^{-}$, in contrast to $\mathrm{OH}^{-}$, they are considered as potential mutagens because they can engender the release of the Fenton-active ferrous iron, thus leading to the production of $\mathrm{OH}^{-}$which can cause lesions on DNA (reviewed by Imlay, 2003). The overproduction of ROS and the resultant depletion of antioxidants lead oxidative stress, whereas this situation could be reversed gradually, probably because of the induction of antioxidant synthesis and antioxidant enzyme activation (Boldt and Scandalios, 1997; Foyer et al. 1994; Halliwell and Gutteridge 1999). In addition to the protective role of CAT mentioned previously, in our study, other enzymes that were not measured, such as peroxidases (Sundaram and Soumya, 2011), could be additionally involved in scavenging $\mathrm{H}_{2} \mathrm{O}_{2}$. We cannot determine if the increased resistance to ROS was due to other photoprotective mechanisms or repair processes which might be induced concomitantly together with increased CAT activity. The highly efficient DNA repair systems in cyanobacteria (He et al. 2002), allow these most ancient organisms to survive several environmental stresses during evolution and adapt to these stresses (Ehling-Schulz and Scherer, 1999).

The actual effect of temperature on metabolic rate is complicated by species-specific or ecotype-specific temperature ranges and optima for growth, as demonstrated in ecotypes of Prochlorococcus (Zinser et al., 2007). However, despite the apparent DNA protection by increased CAT activity, Chl $a$ was much more vulnerable to the presence of ROS as discussed previously in relation to $\mathrm{Q}_{\mathrm{Chl-a}}$ observed.

Van der Westhuizen and Eloff (1985) determined that temperature has the most pronounced effect on toxicity of $M$. aeruginosa. In our study we observed a significant decrease of cellular [Leu ${ }^{1}$ ]MC-LR in to the $29^{\circ} \mathrm{C}$ treatment compared to $23^{\circ} \mathrm{C}$ and control starting after $24 \mathrm{~h}$ of exposure and until the end of the exponential growth of the cultures. The same results were observed for the 2 order low cellular concentration of: $\mathrm{Q}_{[\text {Leu1,Asp3] MC-LR }} ; \mathrm{Q}_{[\text {Leu1,Glu(OCH3)6]MC-LR }}$ and $\mathrm{Q}_{[\mathrm{M}(\mathrm{O}) 1] \mathrm{MC}-\mathrm{LR}}$ reaching the addition of all this $4 \mathrm{MCs}$ around $16 \mathrm{fg} \mathrm{cells}^{-1}$ in control treatments. Dziallas and Grossart (2011) hypothesize that microcystins function as radical scavengers. Recently, Zilliges et al. (2011) proposed that microcystin can bind to some phycobilins and thus, protects them from degradation by reactive oxygen species. The apparent loss of MC is likely the consequence of a specific and covalent binding of the toxin to various proteins (Meissner et al., 2013, 2014). This binding is strongly enhanced under high light conditions suggesting an important intracellular function of MC during acclimation of Microcystis to oxidative stress conditions (Zilliges et al., 2011). Jüttner and Lüthi (2008) showed that toxin bind to antennae proteins, while Vela et al. (2008) reported the association of MC with a set of proteins in vitro and in vivo. Under high light and oxidative stress conditions, non-covalent interaction is then strengthened by covalent interactions of cysteines and the $\mathrm{N}$-methyldehydroalanine position of MC. As more evidence supporting the role of MC related to oxidative stress, several studies showed an increased sensitivity of MC-deficient mutants under high light and oxidative stress conditions (Zilliges et al., 2011; Meissner et al., 2015; Makower et al., 2015). In addition, Briand et al. (2008) observed a decrease in MC cell quota in the late exponential growth phase. In the light of the findings of our study, this decrease could be related to an increase in MC binding to proteins in senescent cultures that are accumulating ROS. Results from Dziallas and Grossart (2011) showed that MCs weaken the detrimental effect of $\mathrm{H}_{2} \mathrm{O}_{2}$ on $M$. aeruginosa and that toxin production is temperature dependent. More over, these authors demonstrated that warmer environments are often characterized by more radicals with a higher potential for cell damage (e.g., due to higher diffusibility), and proposed a function of cyanobacterial toxins as radical scavengers being relevant for cyanobacterial growth at elevated temperatures.

Amé and Wunderlin (2005) showed that for natural samples of Microcystis, the percentage of MC-LR:MC-RR was higher at higher temperatures $\left(28^{\circ} \mathrm{C}\right)$ compared to that at lower temperatures $\left(20^{\circ} \mathrm{C}\right)$. This is in contrast to a study by Rapala et al. (1997) that found lower MC-LR concentration associated to lower temperatures $\left(<25^{\circ} \mathrm{C}\right)$ while higher MC-RR concentration were correlated to higher temperatures $\left(>25^{\circ} \mathrm{C}\right)$ for Anabaena strains. In our case, different temperatures induce a significant change in the MC profile showing an increasing proportion of MC-LR at $29{ }^{\circ} \mathrm{C}$ over total MCs after 4 days exposure (Fig. 8). From such comparison, we may predict that MC-LR from different cyanobacterial species could have different responses to a temperature increase. Genome sequencing and characterization of the MC synthetase gene clusters in Microcystis species has elucidated the roles of various mcy genes in the MC biosynthesis pathway (Nishizawa et al., 2000). Our results, as well as those from Qi et al. (2015) showed that an isolated strain of $M$. aeruginosa may produce different structural variants of MCs. It can be explained by the multispecificity of single domains of the MC biosynthesis complex. In particular, the first module of mcy B can incorporate a variety of different amino acids at the variable $\mathrm{X}$ position within the MC structure (Christiansen et al., 2003). At this variable position, $\left[\right.$ Leu $\left.^{1}\right]$ MC-LR contains leucine, whereas MC-LR contains alanine (one of the smaller amino acids). Our results show that the composition of MC variants may change with increased temperature. The cell quota of 4 of the $5 \mathrm{MC}$ variants determined decreased (see above), whereas the $Q_{\text {MC-LR }}$ increased starting after $24 \mathrm{~h}$ of exposure. In order to try to explain such findings, we could hypothesize that a conformational change in the substrate-binding place of the first module of the mcy B enzyme could lead to a change in the substrate specificity of the module. A plausible alternative explanation could be that increasing temperature conditions induce changes in the composition of available amino acids, resulting in a shift in MC synthesis from [Leu ${ }^{1}$ ]MC-LR to MC-LR. Further research is needed to confirm this possibility. Mowe et al. (2015) for tropical Microcystis strains, found that high temperatures $\left(30,33\right.$, and $\left.36{ }^{\circ} \mathrm{C}\right)$ may lead to a greater dominance of a more toxic variant (MC-LR) in M. ichthyoblabe. However, in contrast with our temperate strain, they didn't find any significant increasing of MC-LR for M. aeruginosa comparing $27,30,33$ and $36{ }^{\circ} \mathrm{C}$ but with a coincident decrease in MC quota with increasing temperature.

\section{Conclusions}

During present investigation we found a significant increase in ROS induced by a temperature shift from control $\left(26{ }^{\circ} \mathrm{C}\right)$ to $23{ }^{\circ} \mathrm{C}$ and $29^{\circ} \mathrm{C}$, respectively. However, the antioxidant CAT enzymes were more active under stress as improved scavenging activity with a decrease in ROS concentration and a consequent increased growth at high temperature. Interestingly, the $M$. aeruginosa isolate from a temperate environment, was able to cope with the potential damage caused by an increase in oxidant species due to a temperature change between 23 and $29^{\circ} \mathrm{C}$. The formation of $\mathrm{OH}^{-}$can be significantly inhibited by CAT, indicating that $\mathrm{H}_{2} \mathrm{O}_{2}$ is also generated in the system and acts as a potential source of $\mathrm{OH}^{-}$with the potential damage to DNA. Such results could explain the delay of the start of exponential growth at low temperature and, as well as the significant decreased $\mathrm{Chl}$ a concentration due to temperature change.

Our findings support the hypothesis that M. aeruginosa may have a greater competitive advantage over other species at higher mean water temperatures such as $29^{\circ} \mathrm{C}$. The mean temperature of the Río 
de la Plata (Argentina) and its adjacent region during the warm period (November-March) is around $25{ }^{\circ} \mathrm{C}$ (Guerrero et al., 2010). M. aeruginosa was monitored in the area (Giannuzzi et al., 2012) and MCs were detected in drinking water (Echenique et al., 2014). From our results we may predict that increasing temperatures up to $29{ }^{\circ} \mathrm{C}$ (projected higher mean water temperature under climate change) could produce a decreased total MC cell quota in M. aeruginosa but leading to higher proportions of the more toxic MC-LR variant (Kotak et al., 1995). Therefore, continued climatic warming could lead to a dominance of $M$. aeruginosa populations including blooms that contain a greater percentage of cells with high concentrations of MC-LR. Moreover, because MCs are chemically very stable and do not readily undergo proteolytic or hydrolytic attack (Yu et al., 2009), these toxins can finally end up in human food through the food chain or drinking water, and the chronic impact of accumulated MCs on human health cannot be ignored (Chen et al., 2009).

\section{Acknowledgements}

This study was supported by grants from the University of Buenos Aires (20020130100383BA), ANPCyT and CONICET (PIP 0697). This study is part of the IMCONet - Interdisciplinary Modelling of Climate Change in Coastal Western Antarctica - Network for Staff Exchange and Training FP7-PEOPLE-2012-International Research Staff Exchange Scheme (IRSES) 318718. We acknowledge Dr. S. Díaz who shared the Biospherical Inc. radiometer and Drs. Opezzo, Pizarro, Costa and her group for laboratory support.

\section{References}

Amé, M.V., Wunderlin, D.A., 2005. Effects of iron, ammonium and temperature on microcystin content by a concentrated Microcystis aeruginosa natural population. Water Air Soil Pollut. 168, 235-248.

Asada, K., 1999. The water-water cycle in chloroplasts: scavenging of active oxygens and dissipation of excess photons. Annu. Rev. Plant Physiol. 50, 601-639.

Briand, E., Yéprémian, C., Humbert, J.F., Quiblier, C., 2008. Competition between microcystin- and non-microcystin-producing Planktothrix agardhii (cyanobacteria) strains under different environmental conditions. Environ. Microbiol. 10, 3337-3348.

Beutler, E., 1982. Catalase. In: Beutler, E. (Ed.), Red Cell Metabolism a Manual Of Biochemical Methods. Grune and Stratton, Inc, pp. 105-106.

Boldt, R., Scandalios, J.G., 1997. Influence of UV-light on the expression of the Cat2 and Cat3 catalase genes in maize. Free Radic. Biol. Med. 23, 505-514.

Carpenter, S.R., Caraco, N.F., Correll, D.L., Howarth, R.W., Sharpley, A.N., Smith, V.H., 1998 Nonpoint pollution of surface waters with phosphorus and nitrogen. Ecol. Appl. 8 559-568.

Codd, G.A., Bell, S.G., Kaya, K., 1999. Cyanobacterial toxins, exposure routes and human health. Eur. J. Phycol. 34, 405-415.

Chelikani, P., Fita, I., Loewen, P.C., 2004. Diversity of structures and properties among catalases. Cell. Mol. Life Sci. 61, 192-208.

Chen, J., Xie, P., Li, L., Xu, J., 2009. First identification of the hepatotoxic microcystins in the serum of a chronically exposed human population together with indication of hepatocellular damage. Toxicol. Sci. 108, 81-89.

Chorus, I., Bartram, J., 1999. Toxic Cyanobacteria in Water: a Guide to Their Public Health Consequences, Monitoring and Management. World Health Organization/E\&FN Spon/Routledge, London.

Christiansen, G., Fastner, J., Erhard, M., Borner, T., Dittmann, E., 2003. Microcystin biosynthesis in Planktothrix: genes, evolution, and manipulation. J. Bacteriol. 185, 564-572

Dziallas, C., Grossart, H., 2011. Increasing oxygen radicals and water temperature select for toxic Microcystis sp. PLoS One 6 (9), 25569.

Dawson, R.M., 1998. The toxicology of microcystins. Toxicon 36, 953-962.

Dietrich, D., Hoeger, S., 2005. Guidance values for microcystins in water and cyanobacterial supplement products (blue-green algal supplements): a reasonable or misguided approach? Toxicol. Appl. Pharmacol. 203, 273-289.

Echenique, R., Aguilera, A., Giannuzzi, L., 2014. Problems on drinking water related to toxigenic Cyanobacteria: some cases studied in Argentina. Fundam. Appl. Limnol. $65,431$.

Ehling-Schulz, M., Scherer, S., 1999. UV protection in cyanobacteria. Eur. J. Phycol. 34, 329-338.

Giannuzzi, L., Carvajal, G., Corradini, M.G., Araujo Andrade, C., Echenique, R., Andrinolo, D. 2012. Occurrence of toxic cyanobacterial blooms in Rio de la Plata Estuary, Argentina: field study and data analysis. J. Toxicol., 373618 http://dx.doi.org/10.1155/2012/ 373618 (15 pages).

Gomes, A., Fernandes, E., Lima, J.L.F.C., 2005. Fluorescence probes used for detection of reactive oxygen species. J. Biochem. Biophys. Methods 65, 45-80.

Guerrero, R.A., Piola, A.R., Molinari, G.N., Osiroff, A.P., Jáuregui, S.I., 2010. Climatología de temperatura y salinidad en el Río de La Plata y su frente marítimo. INIDEP contribution $\mathrm{N}^{\circ} 1555$, Argentina-Uruguay (60 pp.).
Halliwell, b., 2006. Reactive species and antioxidants. Redox biology is a fundamental theme of aerobic life. Plant Physiol. 141 (2), 312-322.

Halliwell, B., Gutteridge, J.M.C., 2007. Free Radicals in Biology and Medicine. third ed. Oxford University Press, Oxford.

Häubner, N., Sylvander, P., Vuori, K., Snowijs, P., 2014. Abiotic stress modifies the synthesis of alpha-tocopherol and beta-carotene in phytoplankton species. J. Phycol. 50 (4), 753-759.

He, Y.Y., Klisch, M., Häder, D.P., 2002. Adaptation of cyanobacteria to UV-B stress correlated with oxidative stress and oxidative damage. Photochem. Photobiol. 76 (2), 188-196.

Hotto, A.M., Satchwell, M.F., Betty, D.L., Gobler, C.J., Boyer, G.L., 2008. Spatial and temporal diversity of microcystins and microcystin-producing genotypes in Oneida Lake, NY. Harmful Algae 7, 671-681.

Houghton, J.T., Ding, Y., Griggs, D.J., Noguer, M., Van Der Lin-Den, P.J., Dai, X., Maskell, K., Johnson, C.A., 2001. Climate Change 2001: the Scientific Basis. Cambridge University Press, Cambridge, p. 881.

Imai, H., Kwang-Hyeon, C., Kusaba, M., Nakano, S.-I., 2009. Temperature-dependent dominance of Microcystis (Cyanophyceae) species: M. aeruginosa and M. wesenbergii. J. Plankton Res. 31 (2), 171-178.

Imlay, J.A., 2003. Pathways of oxidative damage. Annu. Rev. Microbiol. 57, 395-418.

Jakubowski, W., Bartosz, G., 2000. 2,7-dichlorofluorescin oxidation and reactive oxygen species: what does it measure? Cell Biol. Int. 24 (10), 757-760.

Jeffrey, S.W., Humphrey, G.F., 1975. New spectrophotometric equation for determining chlorophyll $a$, b, c1 and c2. Biochem. Mol. Biol. Plant Horm. 167, 194-204.

Jüttner, F., Lüthi, H., 2008. Topology and enhanced toxicity of bound microcystins in Microcystis PCC 7806. Toxicon 51, 388-397.

Kotak, B.G., Lam, A.K.-Y., Prepas, E.E., Kenefick, S.L., Hrudey, S.E., 1995. Variability of the hepatotoxin microcystin-LR in hypereutrophic drinking water lakes. J. Phycol. 31, 248-263.

Krüger, T., Wiegand, C., Kun, L., Luckas, B., Pflugmacher, S., 2010. More and more toxins around - analysis of cyanobacterial strains isolated from Lake Chao (Anhui Province, China). Toxicon 56, 1520-1524.

Kurmayer, R., Dittmann, E., Fastner, J., Chorus, I., 2002. Diversity of microcystin genes within a population of the toxic cyanobacterium Microcystis spp. in Lake Wannsee. Microb. Ecol. 43 (1), 107-118.

Kurmayer, R., Kutzenberger, T., 2003. Application of real-time PCR for quantification of microcystin genotypes in a population of the toxic cyanobacterium Microcystis sp. Appl. Environ. Microbiol. 69, 6723-6730.

Lafiti, A., Ruiz, M., Zhang, C.C., 2009. Oxidative stress in cyanobacteria. FEMS Microbiol. Rev. 33, 258-278.

Li, M., Nkrumah, P.N., Xiao, M., 2014. Biochemical composition of Microcystis aeruginosa related to specific growth rate: insight into the effects of abiotic factors. Inland Waters 4, 357-362.

Makower, A.K., Schuurmans, J.M., Groth, D., Zilliges, Y., Matthijs, H.C.P., Dittmann, E., 2015. Transcriptomics-aided dissection of the intracellular and extracellular roles of microcystin in Microcystis aeruginosa PCC 7806. Appl. Environ. Microbiol. 81, 544-554.

Malanga, G., Juarez, A.B., Albergheria, J.S., Velez, C.G., Puntarulo, S., 2001. Efecto de la radiación UVB sobre el contenido de ascorbato y radical ascorbilo en algas verdes. In: Alveal, K., Antezana, T. (Eds.), Sustentabilidad de la Biodiversidad, un problema actual, bases científico-técnicas. teorizaciones y proyecciones, Concepción, Chile, pp. 389-398.

Martin, T., 2000. Cianobacterial dominance in lakes. Hydrobiology 438, 1-12.

McDowell, R.E., Amsler, C.D., Dickinson, D.A., McClintock, J.B., Baker, B.J., 2013. Reactive oxygen species and the Antarctic macroalgal wound response. J. Phycol. 50, 71-80.

Meissner, S., Fastner, J., Dittmann, E., 2013. Microcystin production revisited: conjugate formation makes a major contribution. Environ. Microbiol. 15 (6), 1810-1820.

Meissner, S., Steinhauser, D., Dittmann, E., 2014. Metabolomic analysis indicates a pivotal role of the hepatotoxin microcystin in high light adaptation of Microcystis. Environ. Microbiol. 17 (5), 1497-1509.

Michaeli, A., Feitelson, J., 1995. Reactivity of singlet oxygen toward large peptides. Photochem. Photobiol. 61, 255-260.

Meissner, S., Steinhauser, D., Dittmann, E., 2015. Metabolomic analysis indicates a pivotal role of the hepatotoxin microcystin in high light adaptation of Microcystis. Environ. Microbiol. 17, 1497-1509.

Mittler, R., 2002. Oxidative stress, antioxidants and stress tolerance. Trends Plant Sci. 7, 405-410.

Mowe, M.A.D., Porojan, C., Abbas, F., Mitrovic, S.M., Lim, R.P., Furey, A., Yeo, D.C.J., 2015. Rising temperatures may increase growth rates and microcystin production in tropical Microcystis species. Harmful Algae 50, 88-98.

Nishizawa, T.A., Ueda, M., Asayama, K., Fujii, K., Harada, K., Ochi, K., Shirai, M., 2000. Polyketide synthase gene coupled to the peptide synthetase module involved in the biosynthesis of the cyclic heptapeptide mycrocistin. J. Biochem. 127 (5), 779-789.

Ohkubo, N., Yagi, O., Okada, M., 1993. Studies on the succession of blue-green algae, Microcystis, Anabaena, Oscillatoria and Phormidium in Lake Kasumigaura. Environ. Technol. 14, 433-442.

Oliver, R.L., Gand, G.G., 2000. Freshwater blooms. In: Whiton, B.A., Potts, M. (Eds.), The Ecology of Cyanobacteria. Kluwer Academic Press, Dordrecth, pp. 149-194.

Orr, P.T., Jones, G.J., 1998. Relationship between microcystin production and cell division rates in nitrogen-limited Microcystis aeruginosa cultures. Limnol. Oceanogr. 43, 1604-1614.

Ouzounidou, G., 1995. Cu-ions mediated changes in growth, chlorophyll and other ion contents in a Cu-tolerant Koeleria splendens. Biol. Plant. 37, 71-78.

Paerl, H.W., Huisman, J., 2008. Blooms like it hot. Science 320, 57-58.

Pflugmacher, S., 2002. Possible allelopathic effects of cyanotoxins, with reference to microcystin-LR, in aquatic ecosystems. Environ. Toxicol. 17, 407-413. 
Qi, Rosso, L., Sedan, D., Andrinolo, D., Dietrich, V., 2015. Seven new microcystin variants discovered from a native Microcystis aeruginosa strain? Unambiguous assignment of product ions by tandem mass spectrometry. Rapid Commun. Mass Spectrom. 29, 220-224.

Rapala, J., Sivonen, K., Lyra, C., Niemelä, S.I., 1997. Variation of microcystins, cyanobacterial hepatotoxins, in Anabaena spp. as a function of growth stimuli. Appl. Environ. Microbiol. 63, 2206-2212.

Reynolds, C.S., 2006a. The Ecology of Phytoplankton (Ecology, Biodiversity and Conservation). Cambridge University Press, Cambridge, UK.

Rippka, R., Deruells, J., Waterburry, J.B., 1979. Generic assignments, strain histories and properties of pure cultures of cyanobacteria. J. Gen. Microbiol. 111, 1-61.

Raven, J.A., Caldeira, K., Elderfield, H., 2005. Ocean acidification due to increasing atmospheric carbon dioxide. R. Soc. of London 60 Policy document 12/05.

Rosso, L., Sedan, D., Kolman, M., Caixach, J., Flores, C., Oteiza, J.M., Salerno, G., Echenique, R., Giannuzzi, L., Andrinolo, D., 2014. Microcystis aeruginosa strain [D-Leu1] Mcyst-LR producer, from Buenos Aires province, Argentina. J. Coast. Life Med. 2, 287.

Saison, C., Perreault, F., Daigle, J.-C., Fortin, C., et al., 2010. Effect of core-shell copper oxide nanoparticles on cell culture morphology and photosynthesis (Photosystem II energy distribution) in the green alga, Chlamydomonas reinhardtii. Aquat. Toxicol. 96 (2), 109-114.

Scheiner, S.M., 2001. MANOVA: multiple response variables and multispecies interactions. In: Scheiner, G. (Ed.), Design and Analysis of Ecological Experiments, second ed. Oxford Univ. Press, Oxford.

Sedmak, B., Elersek, T., 2006. Microcystins induce morphological and physiological changes in selected representative phytoplanktons. Microb. Ecol. 51, 508-515.

Singh, D.P., Tyagi, M.B., Kumar, A., Thakur, J., 2001. Antialgal activity of a hepatotoxinproducing cyanobacterium, Microcystis aeruginosa. World J. Microbiol. Biotechnol. $17,15-22$.

Sundaram, S., Soumya, K.K., 2011. Study of physiological and biochemical alterations in cyanobacterium under organic stress. Am. J. Plant Physiol. 6 (1), 1-16.

Tillmann, U., Alpermann, T., Purificacao, R., Krock, B., Cembella, A., 2009. Intrapopulation clonal variability in allelochemical potency of the toxigenic dinoflagellate Alexandrium tamarense. Harmful Algae 8, 759-769.
Valavanidis, A., Vlahogianni, T., Dassenakis, M., Scoullosv, M., 2006. Molecular biomarkers of oxidative stress in aquatic organisms in relation to toxic environmental pollutants. Ecotoxicol. Environ. Saf. 64, 178-189.

Van Der Westhuizen, A.J., Eloff, J.N., 1985. Effects of temperature and light on toxicity and growth of the blue-green alga Microcystis aeruginosa [UV-006]. Planta 163. 5559.

Vela, L., Sevilla, E., Gonzalez, C., Bes, M.T., Fillat, M.F., 2008. Exploring the interaction of microcystin-LR with proteins and DNA. Toxicol. in Vitro 22, 1714-1718.

Villafañe, V.E., Reid, F.M.H., Ferrario, M.E., Oliveira, E.C., 1995. Métodos de microscopia para la cuantificación del fitoplancton. In: Aveal, K. (Ed.), Manual de métodos ficológicos. Universidad de Concepción, Concepción, pp. 169-185.

Yoshida, M., Yoshida, T., Takashima, Y., Hosoda, N., Hiroishi, S., 2007. Dynamics of microcystin-producing and non-microcystinproducing Microcystis populations is correlated with nitrate concentration in a Japanese lake. FEMS Microbiol. Lett. 266, 49-53.

Yu, T., Xie, P., Dai, M., Liang, G.D., 2009. Determinations of MC-LR and [Dha7] MC-LR concentrations and physicochemical properties by liquid chromatography-tandem mass spectrometry. Bull. Environ. Contam. Toxicol. 83, 757-760.

Zegura, B., Sedmak, B., Filipic, M., 2003. Microcystin-LR induces oxidative DNA damage in human hepatoma cell line HepG2. Toxicon 41 (1), 41-48.

Zinser, E.R., Johnson, Z.I., Coe, A., Karaca, E., Veneziano, D., Chisholm, S.W., 2007. Influence of light and temperature on Prochlorococcus ecotype distributions in the Atlantic Ocean. Limnol. Oceanogr. 52, 2205-2220.

Zilliges, I., Kehr, J.C., Meissner, S., Ishida, K., Mikkat, S., 2011. The cyanobacterial hepatotoxin microcystin binds to proteins and increases the fitness under oxidative stress conditions. PLoS One http://dx.doi.org/10.1371/journal.pone.0017615.

Zuo, F., Yu, R., Feng, X., Khaskheli, G.B., Chen, L., Ma, H., Chen, S., 2014. Combination of heterogeneous catalase and superoxide dismutase protects Bifidobacterium longum strain NCC2705 from oxidative stress. Appl. Microbiol. Biotechnol. 98 (17), 7523-7534. 